\title{
Protective effects and mechanisms of Terminalia catappa L. methenolic extract on hydrogen-peroxide-induced oxidative stress in human skin fibroblasts
}

\author{
Ya-Han Huang ${ }^{1}$, Po-Yuan Wu ${ }^{2,3}$, Kuo-Ching Wen ${ }^{1}$, Chien-Yih Lin ${ }^{4 *}$ and Hsiu-Mei Chiang ${ }^{1 *}$
}

\begin{abstract}
Background: Oxidative stress plays a crucial role in aging-related phenomenon, including skin aging and photoaging. This study investigated the protective role and possible mechanism of Terminalia catappa L. methanolic extract (TCE) in human fibroblasts ( $\mathrm{Hs68})$ against hydrogen peroxide $\left(\mathrm{H}_{2} \mathrm{O}_{2}\right)$-induced oxidative damage.

Methods: Various in vitro antioxidant assays were performed in this study. The effect and mechanisms of TCE on oxidative stress-induced oxidative damage were studied by using western blotting.

Results: The $\mathrm{IC}_{50}$ of TCE was $8.2 \mu \mathrm{g} / \mathrm{mL}$ for 1,1-diphenyl-2-picrylhydrazyl radical scavenging, $20.7 \mu \mathrm{g} / \mathrm{mL}$ for superoxide anion radical scavenging, $173.0 \mu \mathrm{g} / \mathrm{mL}$ for $\mathrm{H}_{2} \mathrm{O}_{2}$ scavenging, $44.8 \mu \mathrm{g} / \mathrm{mL}$ for hydroxyl radical scavenging, and $427.6 \mathrm{\mu g} / \mathrm{mL}$ for ferrous chelation activities. Moreover, TCE inhibited the $\mathrm{H}_{2} \mathrm{O}_{2}$-induced mitogen-activated protein kinase signaling pathway, resulting in the inhibition of c-Jun, c-Fos, matrix metalloproteinase (MMP)-1, MMP-3, MMP-9, and cyclooxygenase-2 expression. TCE also increased hemeoxygenase-1 expression inhibited by $\mathrm{H}_{2} \mathrm{O}_{2}$. Finally, TCE was demonstrated reverse type I procollagen expression in fibroblasts after $\mathrm{H}_{2} \mathrm{O}_{2}$ treatment.
\end{abstract}

Conclusions: According to our findings, TCE is a potent antioxidant and protective agent that can be used in antioxidative stress-induced skin aging.

Keywords: Oxidative stress, Reactive oxygen species, Aging, Hemeoxygenase-1 (HO-1), Extracellular matrix

\section{Background}

Aging can be divided into two basic processes: intrinsic aging, which is related to age, and extrinsic aging, which is generally due to long-term exposure to environmental factors, including ultraviolet (UV) light and pollutants. Oxidative stress plays a crucial role in aging-related disorders, including atherosclerosis, cardiovascular diseases and skin aging [1]. High levels of reactive oxygen species (ROS), such as hydrogen peroxide $\left(\mathrm{H}_{2} \mathrm{O}_{2}\right)$, superoxide anion, and singlet oxygen, can cause oxidative damage to cellular DNA, protein, and lipids, resulting in the initiation or development of various disorders and diseases

\footnotetext{
*Correspondence: yihlin@asia.edu.tw; hmchiang@mail.cmu.edu.tw

${ }^{4}$ Department of Biotechnology, Asia University, 500 Liufeng Road, Wufeng

District, Taichung City 41354, Taiwan

'Department of Cosmeceutics, China Medical University, 91 Hsueh-Shih

Road, Taichung 40402, Taiwan

Full list of author information is available at the end of the article
}

such as cardiovascular diseases, type 2 diabetes mellitus, and cancer [2]. In addition, free transition metal ions combine with $\mathrm{H}_{2} \mathrm{O}_{2}$ and can cause extensive oxidative damage to biomolecules such as lipids, proteins, and nucleic acids, leading to age-related disorders [3].

Skin aging is characterized by a sagging appearance, wrinkles, and pigmentary changes, and principally manifests as the degradation of extracellular matrix (ECM) proteins, including type I collagen, elastin, proteoglycans, and fibronectin [4, 5]. Type I collagen is the most abundant structural protein in skin connective tissue and is primarily synthesized by fibroblasts, whereas collagen in the dermis is responsible for skin strength and resiliency [6, 7]. Oxidative stress or inflammation can cause collagen degradation resulting in wrinkle formation and sagging skin [8]. In addition, ROS activate the mitogen-activated protein kinase (MAPK) pathway, which subsequently induces

(c) The Author(s). 2018 Open Access This article is distributed under the terms of the Creative Commons Attribution 4.0 International License (http://creativecommons.org/licenses/by/4.0/), which permits unrestricted use, distribution, and reproduction in any medium, provided you give appropriate credit to the original author(s) and the source, provide a link to the Creative Commons license, and indicate if changes were made. The Creative Commons Public Domain Dedication waiver (http://creativecommons.org/publicdomain/zero/1.0/) applies to the data made available in this article, unless otherwise stated. 
the expression and activation of matrix metalloproteinases (MMPs) in human skin [9]. The activation of MAPK and MMPs may cause damage and aging of the skin $[10,11]$. Agents that can elevate ECM protein levels or downregulate collagen-degrading enzymes, such as MMPs, may prove useful in the development of effective antiaging agents $[12,13]$.

Terminalia catappa L. belongs to the family Combretaceae, and in Southeast Asia, it is commonly used as a folk medicine for treating hepatoma and hepatitis [14, 15]. The leaf and bark extracts of $T$. catappa have been reported to exhibit chemopreventive, antioxidant, hepatoprotective, and anti-inflammatory activities $[16,17]$. T. catappa includes the phytochemicals of flavanoids (rutin, isoorientin, vitexin, and isovitexin), tannins (chebulagic acid, punicalagin, punicalin, and terflavins $\mathrm{A}$ and $\mathrm{B}$ ), and triterpenoids (asiatic acid and ursolic acid) [14, 18]. In addition, the $T$. catappa extract exhibits antifungal and antidepressant activities $[19,20]$. Topical application of ointment containing T. catappa was shown to promote wound healing in rats [21], and our previous study demonstrated that the T. catappa L. hydrophilic extract exerts protective effects on UVB-induced photoaging by inhibiting MMPs expression and upregulating type I procollagen expression [22]. However, the activity and related mechanisms of $T$. catappa against oxidative stress-induced skin damaging are unclear. Therefore, this study investigated the effects of T. catappa methanolic extract (TCE) on $\mathrm{H}_{2} \mathrm{O}_{2}$-induced skin damage and on the protein expression of MAPKs, which activate protein-1 (AP-1), MMPs, and type I procollagen in human skin fibroblasts (Hs68).

\section{Methods}

\section{Chemicals}

Fetal bovine serum (FBS), penicillin-streptomycin, trypsinEDTA, and Dulbecco's Modified Eagle's Medium (DMEM) were purchased from Gibco, Invitrogen (Carlsbad, CA, USA). The Bradford reagent was supplied by Bio-Rad Laboratories (Hercules, CA, USA), and Tris and MTT were purchased from USB (Cleveland, $\mathrm{OH}$, USA). Methanol, dimethyl sulfoxide, doxycycline hyclate, calcium chloride $\left(\mathrm{CaCl}_{2}\right), \mathrm{DPPH}, \mathrm{DL}$-dithiothreitol, and all other reagents used in this study were purchased from Sigma-Aldrich Chemicals (St. Louis, MO, USA).

\section{Preparation and quantitation of TCE}

T. catappa leaves were collected in Wufeng, Taichung City, Taiwan, as previously described [22]. The leaves were identified by Professor KC Wen, a professor in Department of Cosmeceutics, China Medical University and a voucher specimen of this material (FCRDSAL-Plants-0003) has been deposited in Functional Cosmeceutics Research \& Development and Safety Assessment Laboratory, China
Medical University, Taiwan. The dried leaves (150 g) were ground and then extracted twice with $2 \mathrm{~L}$ of methanol for $1 \mathrm{~h}$ by using ultrasonication. The extraction liquid was filtrated, and the filtrate was evaporated to dryness in a vacuum to obtain TCE.

The total phenolic content of TCE was measured using the Folin-Ciocalteu reaction, as previously described [23]. Briefly, TCE was mixed with the Folin-Ciocalteu phenol reagent and sodium carbonate, and absorbance was measured at $760 \mathrm{~nm}$. The phenolic content is expressed as microgram GAE/microgram T. catappa leaf dry weight herein.

The total flavonoid content of TCE was determined using the aluminum chloride colorimetric assay, as described elsewhere [23]. Briefly, TCE was mixed with aluminum chloride hexahydrate, potassium acetate, and deionized water, and the absorbance of the mixture was measured at $405 \mathrm{~nm}$ on an enzyme-linked immunosorbent assay (ELISA) reader (Tecan, Grödig, Austria). The flavonoid content is expressed as microgram QE/microgram T. catappa leaf dry weight herein.

\section{DPPH radical scavenging activity assay}

DPPH was mixed with various concentrations of TCE. The mixture was added to a 96-well microplate and incubated at room temperature for $30 \mathrm{~min}$ in the dark. Subsequently, absorbance was measured at $492 \mathrm{~nm}$ on the ELISA reader. Ascorbic acid was used as a positive control [24, 25].

\section{Superoxide anion radical scavenging activity assay}

Dihydronicotinamide-adenine dinucleotide, phenazinemethosulfate, and nitroblue tetrazolium were prepared in $0.1 \mathrm{M}$ phosphate buffered saline (PBS), after which TCE was added. Absorbance was measured at $560 \mathrm{~nm}$ on the ELISA reader.

\section{Determination of peroxide scavenging activity}

The peroxide scavenging activity of TCE was spectrophotometrically detected using a previously described method $[23,26] . \mathrm{H}_{2} \mathrm{O}_{2}$ was prepared in PBS and mixed with various concentrations of TCE. Then, after incubation, absorption was measured at $230 \mathrm{~nm}$ on the ELISA reader.

\section{Hydroxyl radical scavenging activity assay}

The hydroxyl radical scavenging activity assay was performed by mixing TCE, ascorbic acid, deoxyribose, iron (III) chloride, EDTA, $\mathrm{H}_{2} \mathrm{O}_{2}$, a monopotassium phosphate-potassium hydroxide buffer, and distilled water; the mixture was then incubated at $100{ }^{\circ} \mathrm{C}$ for $15 \mathrm{~min}$ and centrifuged. The absorbance of the supernatant was subsequently measured at $532 \mathrm{~nm}$ on a microplate reader (BioTek, Winooski, VT, USA). Mannitol was used as a positive control, and the hydroxyl radical 
scavenging activity of TCE was obtained as the percentage inhibition of deoxyribose degradation $[3,27]$.

\section{Ferrous ion chelating activity assay}

Various concentrations of TCE were mixed with an iron (II) chloride solution. The reaction was initiated after ferrozine was added. Absorbance was then spectrophotometrically measured at $562 \mathrm{~nm}$ on the microplate reader. The results are expressed as the percentage inhibition of the generation of the ferrozine-ferrous complex herein [24].

\section{Measurement of reducing power}

The reducing power of TCE was determined using a previously described method [24, 28]. Various concentrations of TCE were mixed with ferrocyanate and trichloroacetic acid. After centrifugation, the supernatant was mixed with ferric chloride and absorbance was measured at $700 \mathrm{~nm}$. Ascorbic acid and distilled water were used as the positive and negative controls, respectively.

\section{Cell cultures}

Hs68, HaCaT cells, and B16F0 cells were purchased from the Bioresource Collection and Research Center in Hsinchu, Taiwan. These cells were maintained in DMEM containing 10\% FBS, $100 \mathrm{U} / \mathrm{mL}$ penicillin, and $100 \mathrm{U} / \mathrm{mL}$ streptomycin in an incubator set at $37^{\circ} \mathrm{C}$.

\section{Cell viability assay for three skin cell lines}

To understand the cytotoxicity of TCE on the skin, Hs68, $\mathrm{HaCaT}$ cells, and B16F0 cells were applied to study the cell viability. The cells were seeded in the plate, allowed to attach overnight, and were treated with $1 \mathrm{~mL}$ of various concentrations of TCE dissolved in DMEM for $24 \mathrm{~h}$. The cytotoxicity of TCE was then evaluated using the MTT assay, as described elsewhere [22].

\section{Fluorescence assay for IntracellularROS generation in fibroblasts}

Intracellular ROS generation was measured using a previously detailed method [22]. In brief, fibroblasts were added to a 24-well plate and then incubated with various concentrations of TCE for $24 \mathrm{~h}$. The cells were washed with PBS and incubated with $150 \mu \mathrm{M} \mathrm{H}_{2} \mathrm{O}_{2}$ for $1 \mathrm{~h}$. Subsequently, the cells were incubated with $10 \mu \mathrm{M}$ DCFDA in DMEM for $30 \mathrm{~min}$, after which they were examined under a fluorescence microscope (Leica DMIL, Wetzlar, Germany). Fluorescence (emission wavelength: $520 \mathrm{~nm}$; excitation wavelength: $488 \mathrm{~nm}$ ) was measured on a microplate reader (Thermo Electron Corporation, Vantaa, Finland).

\section{Western blotting}

The cells were incubated with TCE $(5-50 \mu \mathrm{g} / \mathrm{mL})$ for $4 \mathrm{~h}$, followed by incubation with $150 \mu \mathrm{M} \mathrm{H}_{2} \mathrm{O}_{2}$ for $1 \mathrm{~h}$. The cells were collected and lysed with protein extraction buffer, as previously described [22]. An equal amount of protein was loaded, separated on $10 \%$ sodium dodecyl sulfate polyacrylamide gels, and then electrophoretically transferred to a polyvinylidene difluoride membrane. The membrane was incubated with specific antibodies against MMP-1, - 3, and - 9; type I procollagen; HO-1; MAPKs; c-Jun; c-Fos; and COX-2 (Santa Cruz Biotechnology, Inc., Santa Cruz, CA, USA). The blots were then incubated with anti-immunoglobulin G-horseradish peroxidase and chemiluminescent detection reagent (Amersham Biosciences, Buckinghamshire, United Kingdom). Finally, immunoreactive bands were detected using a chemiluminescent detection system (LAS-4000, Fujifilm, Tokyo, Japan), and the density of the bands was determined using a densitometric program (Multi Gauge V2.2, Fujifilm, Tokyo, Japan).

\section{Statistical analyses}

Values are presented as the mean \pm standard deviation of at least three independent experiments. The results were analyzed using one-way analysis of variance, followed by Scheffe's test. Statistical significance was set at $p<0.05$.

\section{Results}

\section{Extraction yield and quantitation of TCE}

The extraction yield of TCE from leaves was $11.5 \%$. The total phenolic content of the extract was determined using the Folin-Ciocalteu method, and the regression coefficient of the calibration curve was 0.9995 . Specifically, the total phenolic content of TCE was $220.2 \pm 0.2 \mu \mathrm{g} / \mathrm{mg}$ gallic acid equivalent (GAE). Additionally, the total flavonoid content of TCE was determined using the aluminum chloride colorimetric method, and the regression coefficient of the calibration curve was 0.9991 . The total flavonoid content was $109.0 \pm 0.8 \mu \mathrm{g} / \mathrm{mg}$ quercetin equivalent (QE). The content of gallic acid was $74.62 \mu \mathrm{g} / \mathrm{mL}$ by HPLC/UV analysis (Additional file 1: S1).

\section{The antioxidant activity of TCE}

The antioxidant activity of TCE was study by using free radical scavenging assay and chelating assay. Figure 1a shows the DPPH radical scavenging activity of TCE and $10 \mu \mathrm{g} / \mathrm{mL}$ ascorbic acid (positive control). The results indicated that $10 \mu \mathrm{g} / \mathrm{mL}$ TCE exhibited a scavenging activity of $70.4 \% \pm 4.9 \%$, and that the activity was $99.0 \% \pm 1.6 \%$ for the same concentration of ascorbic acid. The $\mathrm{IC}_{50}$ of TCE for DPPH scavenging activity was $5.6 \mu \mathrm{g} / \mathrm{mL}$; in other words, TCE preparations exhibited potent DPPH free radical scavenging activity. As shown in Fig. 1b, the superoxide anion radical scavenging activity was $49.5 \% \pm 0.2 \%$ for $250 \mu \mathrm{g} / \mathrm{mL}$ beta hydroxyl acid (BHA) (positive control), and ranged from $73.9 \% \pm 2.1 \%$ to $92.4 \% \pm 2.0 \%$ for $50-1000 \mu \mathrm{g} / \mathrm{mL}$ TCE. The $\mathrm{IC}_{50}$ of TCE 

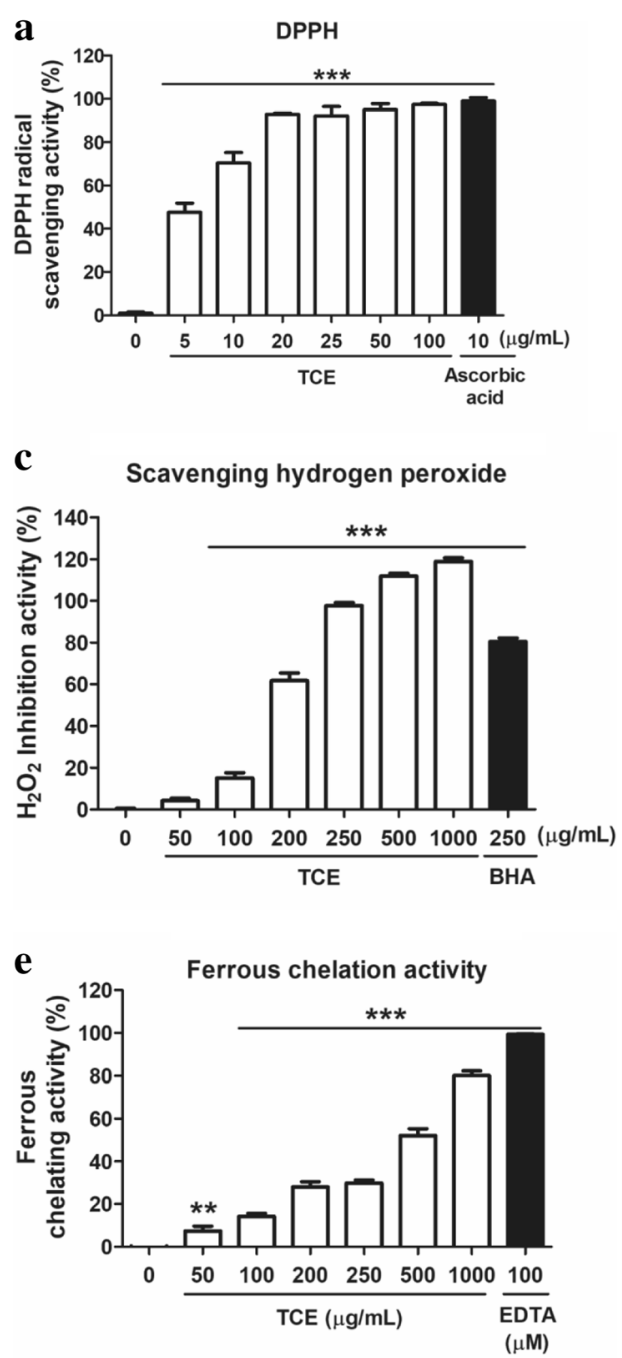

b

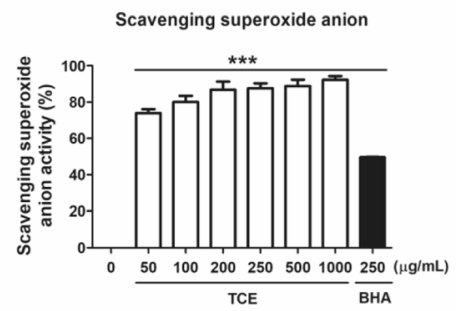

d

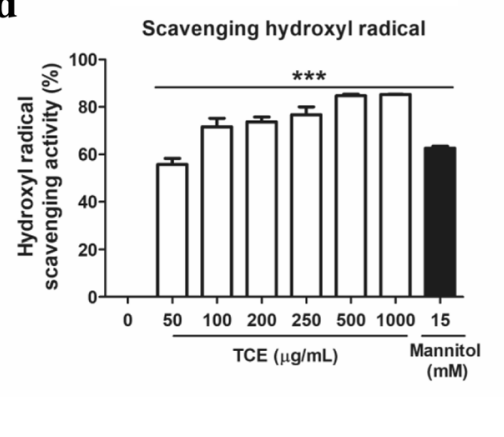

f

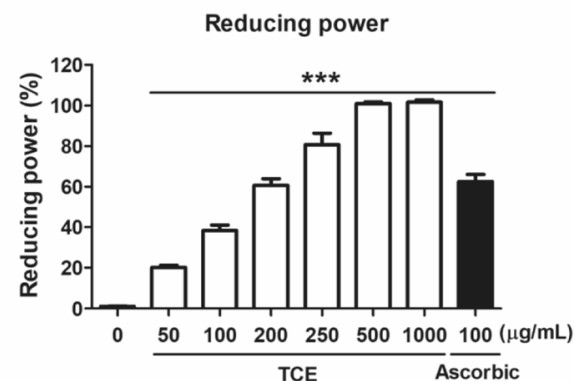

Fig. 1 The aioxidant activity of Terminalia catappa L. methenolic extract (TCE). a 1,1-diphenyl-2-picrylhydrazyl radical scavenging activity of TCE; b Superoxide anion radical scavenging activity of TCE; c Peroxide scavenging activity of TCE; $\mathbf{d}$ Hydroxyl radical scavenging activity of TCE; e Ferrous chelating activity of TCE; and $\mathbf{f}$ Reducing power of TCE. Significant difference versus control (without extract): ${ }^{*} p<0.05 ;{ }^{* *} p<0.01 ;{ }^{* * *} p<0.001$

for superoxide anion radical scavenging was $20.6 \mu \mathrm{g} / \mathrm{mL}$. Thus, the superoxide anion radical scavenging activity of TCE was superior to that of BHA. The peroxide scavenging activities of TCE (50-1000 $\mu \mathrm{g} / \mathrm{mL})$ and the positive control BHA $(250 \mu \mathrm{g} / \mathrm{mL})$ are shown in Fig. 1c. Specifically, the peroxide scavenging activity ranged from $4.2 \% \pm 1.2 \%$ to $111.8 \% \pm 1.3 \%$ for various concentrations of TCE, and was $80.4 \% \pm 1.8 \%$ for BHA. Notably, the peroxide scavenging activity of TCE was superior to that of BHA $\left(\mathrm{IC}_{50}=166.1 \mu \mathrm{g} / \mathrm{mL}\right)$. The hydroxyl radical scavenging activities of TCE $(50-1000 \mu \mathrm{g} / \mathrm{mL})$ and the positive control mannitol $(15 \mathrm{mM})$ are shown in Fig. 1d. Specifically, the hydroxyl radical scavenging activity ranged from $55.7 \% \pm 2.6 \%$ to $85.3 \% \pm 0.1 \%$ for various concentrations of TCE, and was $62.0 \% \pm 0.9 \%$ for mannitol. The $\mathrm{IC}_{50}$ of TCE for hydroxyl radical scavenging was $39.6 \mu \mathrm{g} / \mathrm{mL}$.
Figure 1e shows the metal chelating activities of TCE and the positive control ethylenediaminetetraacetic acid (EDTA). The activities ranged from $7.5 \% \pm 2.1 \%$ to $80.0 \% \pm 2.3 \%$ for various concentrations of TCE $(50-1000 \mu \mathrm{g} / \mathrm{mL})$, and was $99.4 \% \pm 0.1 \%$ for EDTA $(100 \mu \mathrm{M})$. The $\mathrm{IC}_{50}$ of $\mathrm{TCE}$ was $427.6 \mu \mathrm{g} / \mathrm{mL}$ for metal chelation. The reducing power ranged from $20.1 \% \pm 1.0 \%$ to $101.7 \% \pm 1.2 \%$ for $50-1000 \mu \mathrm{g} / \mathrm{mL}$ TCE, whereas the reducing power for $100 \mu \mathrm{g} / \mathrm{mL}$ ascorbic acid (positive control) was $62.6 \% \pm 3.5 \%$ (Fig. 1f). The $\mathrm{IC}_{50}$ of TCE was $128.5 \mu \mathrm{g} / \mathrm{mL}$.

\section{TCE inhibited $\mathrm{H}_{2} \mathrm{O}_{2}{ }^{-}$Induced cytotoxicity and intracellular ROS generation}

Human fibroblasts (Hs68), human keratinocytes (HaCaT), and mouse melanoma cells (B16F0) were treated with 
various concentrations of TCE $(5-100 \mu \mathrm{g} / \mathrm{mL})$, and their cell viability was measured using the 3-(4,5-dimethylthiazo1-2-yl)-2,5-diphenyltetrazolium bromide (MTT) assay. As shown in Fig. 2a, the results indicated that TCE did not exhibit cytotoxic effects in the three skin cell lines; these concentrations were thus applied in subsequent experiments.

As shown in Fig. 2b, cell viability was $67.6 \% \pm 1.7 \%$ after $\mathrm{H}_{2} \mathrm{O}_{2}$ treatment. Cell viability ranged from $72.7 \% \pm 1.8 \%$ to $81.9 \% \pm 3.9 \%$ for $5-50 \mu \mathrm{g} / \mathrm{mL}$ TCE. These results indicated that TCE protects the skin from oxidative stress-induced cytotoxicity.

The 2',7'-dichlorofluorescin diacetate (DCFDA) fluorescence assay was used to qualitatively characterize intracellular ROS generation. As shown in Fig. 2c, ROS levels were markedly higher in $\mathrm{H}_{2} \mathrm{O}_{2}$-exposed fibroblasts than in control cells. Moreover, this increase in ROS generation was attenuated in $\mathrm{H}_{2} \mathrm{O}_{2}$-exposed fibroblasts pretreated with various concentrations of TCE $(5-50 \mu \mathrm{g} / \mathrm{mL})$. ROS generation in $\mathrm{H}_{2} \mathrm{O}_{2}$-exposed fibroblasts increased to 1.7-fold compared with control cells, and significantly decreased to 1.3-fold compared with control cells. TCE at $50 \mu \mathrm{g} / \mathrm{mL}$ decreased $\mathrm{H}_{2} \mathrm{O}_{2}$-induced intracellular ROS generation by $23.1 \%$. Thus, TCE protects the skin from ROS damage.

Inhibition of MAPK phosphorylation through TCE

As shown in Fig. $3 \mathrm{a}, \mathrm{H}_{2} \mathrm{O}_{2}$ induced the phosphorylation of p38, extracellular signal-regulated kinase (ERK), and

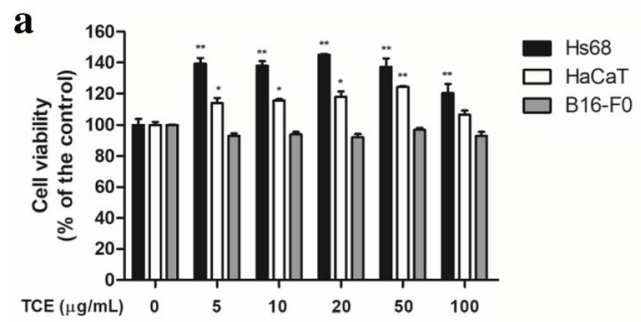

C

(A) Control

(B) $\mathrm{H}_{2} \mathrm{O}_{2} 150 \mu \mathrm{M}$

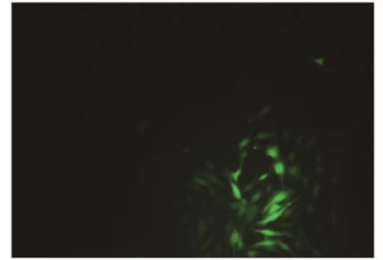

(D) $\mathrm{H}_{2} \mathrm{O}_{2}+$ TCE $10 \mu \mathrm{g} / \mathrm{mL}$

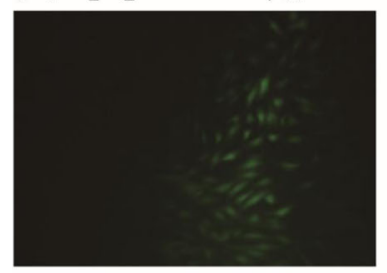

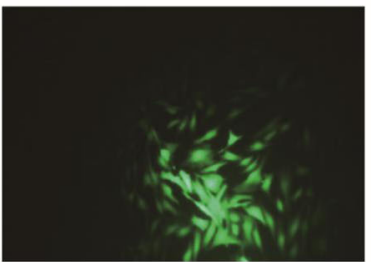

(E) $\mathrm{H}_{2} \mathrm{O}_{2}+\mathrm{TCE} 20 \mu \mathrm{g} / \mathrm{mL}$

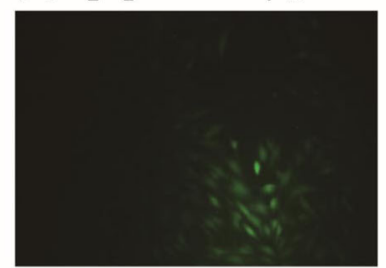

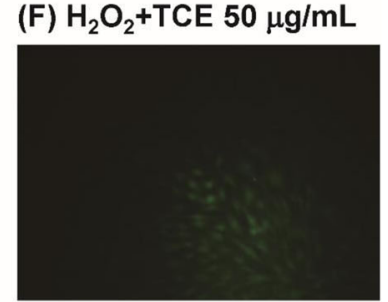

(C) $\mathrm{H}_{2} \mathrm{O}_{2}+\mathrm{TCE} 5 \mu \mathrm{g} / \mathrm{mL}$

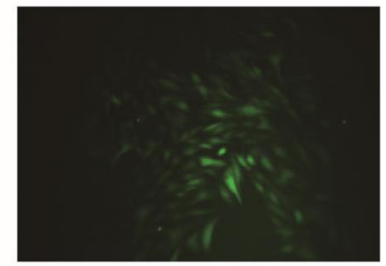

(F) $\mathrm{H}_{2} \mathrm{O}_{2}+$ TCE $50 \mu \mathrm{g} / \mathrm{mL}$
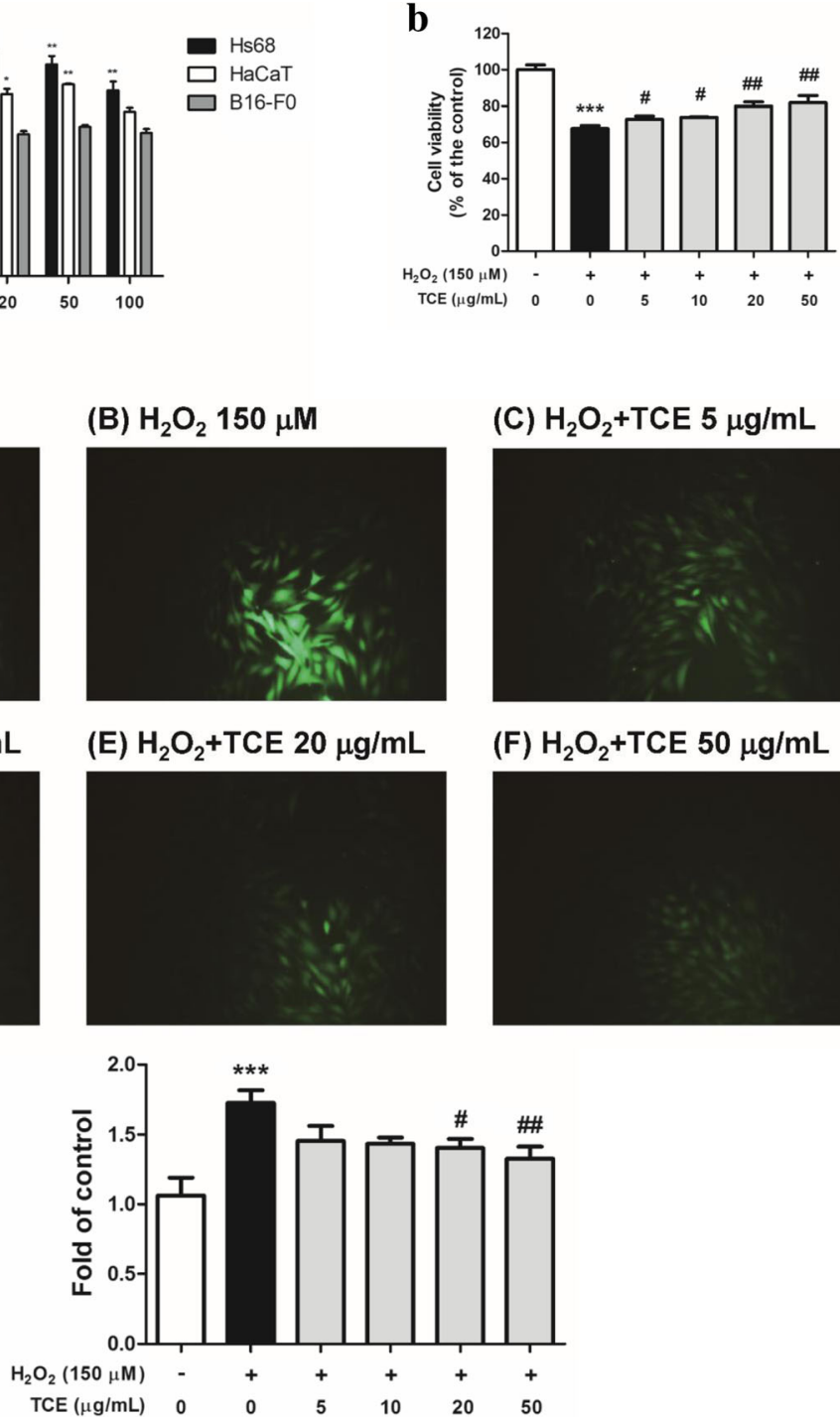

Fig. 2 The cytotoxicity and effect on intracellular oxidative stress in Hs68 of TCE. a Cell viability (\%) of human fibroblasts (Hs68), human keratinocytes, and mouse melanoma cells treated with TCE; $\mathbf{b}$ Cell viability of Hs68 after treatment with TCE with or without $150 \mu \mathrm{M}$ hydrogen peroxide $\left(\mathrm{H}_{2} \mathrm{O}_{2}\right)$ exposure. c Repressive effect of TCE on $\mathrm{H}_{2} \mathrm{O}_{2}$-induced intracellular oxidative stress in Hs68. Significant difference versus control: ${ }^{*} p<0.05 ;{ }^{* *} p<0.01$; ${ }^{* *} p<0.001$. Significant inhibition versus $\mathrm{H}_{2} \mathrm{O}_{2}$-exposed group: ${ }^{*} p<0.05 ;{ }^{\# \#} p<0.01$ 


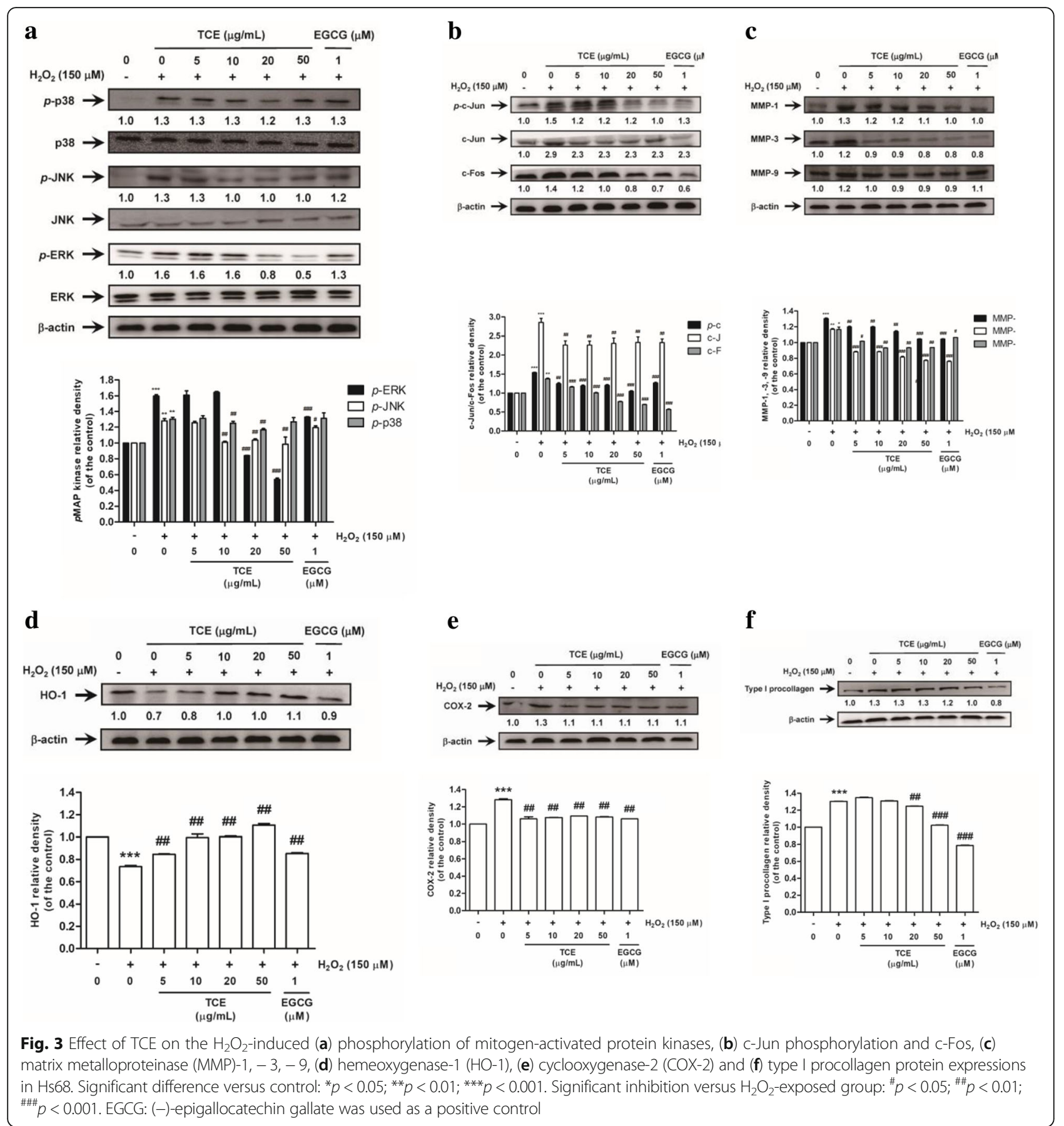

c-Jun N-terminal kinase (JNK). TCE $(5-50 \mu \mathrm{g} / \mathrm{mL})$ dose-dependently inhibited the phosphorylation of ERK, and the effect was significant in the cells treated with $>20 \mu \mathrm{g} / \mathrm{mL}$ TCE. Similar to the effect on ERK, TCE inhibited JNK and p38 activation, which were significantly suppressed when TCE concentration was $20 \mu \mathrm{g} / \mathrm{mL}$.

\section{TCE inhibited phosphorylation of AP-1 in Hs68}

As shown in Fig. $3 \mathrm{~b}, \mathrm{H}_{2} \mathrm{O}_{2}$ increased c-Jun and $p$-c-Jun expression to 1.5- and 2.9-fold that of the control, respectively, whereas $>5 \mu \mathrm{g} / \mathrm{mL}$ TCE significantly reduced the effect. In addition, $\mathrm{H}_{2} \mathrm{O}_{2}$ induced c-Fos expression, but TCE reduced the effect. These results further indicated that TCE protects the skin from oxidative stress-induced damage.

\section{Effect of TCE on MMP expression in $\mathrm{Hs} 68$}

To examine whether TCE protects $\mathrm{H}_{2} \mathrm{O}_{2}$-exposed $\mathrm{Hs} 68$ from oxidative stress-induced damage, the expression of cellular MMP-1, -3 , and -9 proteins was measured. As 
depicted in Fig. 3c, $\mathrm{H}_{2} \mathrm{O}_{2}$ significantly elevated the expression of MMP-1, - 3, and - 9 proteins by 1.3-, 1.2-, and 1.2-fold compared with controls in Hs68, respectively. By contrast, TCE attenuated $\mathrm{H}_{2} \mathrm{O}_{2}$-induced MMP expression. Specifically, treatment with $>5 \mu \mathrm{g} / \mathrm{mL}$ TCE significantly reduced $\mathrm{H}_{2} \mathrm{O}_{2}$-induced $\mathrm{MMP}-1,-3$, and -9 expression. These results indicated that TCE prevents the $\mathrm{H}_{2} \mathrm{O}_{2}$-induced elevation of MMP-1, -3 and - 9 levels, thus protecting the skin from oxidative stress-induced damage.

\section{Effect of TCE on $\mathrm{H}_{2} \mathrm{O}_{2}$-induced Hemeoxygenase-1 expression}

The hemeoxygenase (HO)-1 gene and protein play a pivotal role in the modulation of antioxidant, anti-inflammatory, and antiapoptotic activities. This study revealed that $\mathrm{H}_{2} \mathrm{O}_{2}$ significantly reduces $\mathrm{HO}-1$ protein expression in $\mathrm{Hs} 68$, whereas TCE treatment dose-dependently increases $\mathrm{HO}-1$ expression (Fig. 3d).

\section{Effect of TCE on $\mathrm{H}_{2} \mathrm{O}_{2}$-induced Cyclooxygenase-2 expression in $\mathrm{Hs} 68$}

Cyclooxygenase (COX)-2 levels were 1.3-fold higher in fibroblasts exposed to $150 \mu \mathrm{M} \mathrm{H}_{2} \mathrm{O}_{2}$ than in control cells (Fig. 3e). In addition, various concentrations of TCE $(5-50 \mu \mathrm{g} / \mathrm{mL})$ reduced COX-2 expression; the effect was significant in the cells treated with $>5 \mu \mathrm{g} / \mathrm{mL}$ TCE. These results further confirmed that TCE protects the skin from damage by inhibiting inflammation.

\section{Reversal of $\mathrm{H}_{2} \mathrm{O}_{2}$-induced upregulation of type I procollagen expression in $\mathrm{Hs} 68$ through TCE}

After treatment with $150 \mu \mathrm{M} \mathrm{H}_{2} \mathrm{O}_{2}$, the expression of type I procollagen increased to 1.3-fold compared with that in control cells, whereas TCE inhibited this effect
(Fig. 3f). Notably, treatment of the cells with $50 \mu \mathrm{g} / \mathrm{mL}$ TCE decreased type I procollagen expression to a level similarly expressed in the control cells.

\section{Discussion}

Polyphenols are the second most abundant metabolic products in plants. Notably, plants with high polyphenolic content exhibit potent antioxidant activity [29]. Free radical scavenging activity is related to the polyphenic and flavonoid content of plants. In a previous study, the total phenol content of Rosa hemisphaerica was $138.3 \mu \mathrm{g} / \mathrm{mg}$ GAE [30]. In the present study, the total phenolic content was $220.2 \mu \mathrm{g} / \mathrm{mg}$ GAE dry leaves, the total flavonoid content was $109.0 \mu \mathrm{g} / \mathrm{mg} \mathrm{QE}$ dry leaves, and the $\mathrm{IC}_{50}$ of TCE for $\mathrm{DPPH}$ radical scavenging was $5.6 \mu \mathrm{g} / \mathrm{mL}$. In addition, TCE exhibited strong scavenging activity for ROS including superoxide, peroxide, and hydroxyl radicals. Peroxide is the primary product of initial oxidation, and it can react with ferrous ions, producing more toxic hydroxyl radicals. Iron also has high reactivity and is the pivotal factor in lipid peroxidation catalyzed by transition metals [3]. Furthermore, TCE exhibits potent metal chelating activity and reducing power attenuating features; in the present study, TCE attenuated $\mathrm{H}_{2} \mathrm{O}_{2}$-induced metal chelation, reducing power, ROS generation, and free radical scavenging. Our results suggest that the high polyphenic and flavonoid content of TCE contribute to it potent antioxidant activity.

Molecules such as glutathione, catalase, and HO-1 provide cells, and the body overall, with defense systems against intrinsic and extrinsic oxidative stress. Nuclear factor E2-related factor 2 (Nrf2) and Keap1 are redox-sensitive transcription factors and key intracellular modulators of antioxidant defense against environmental stresses. For

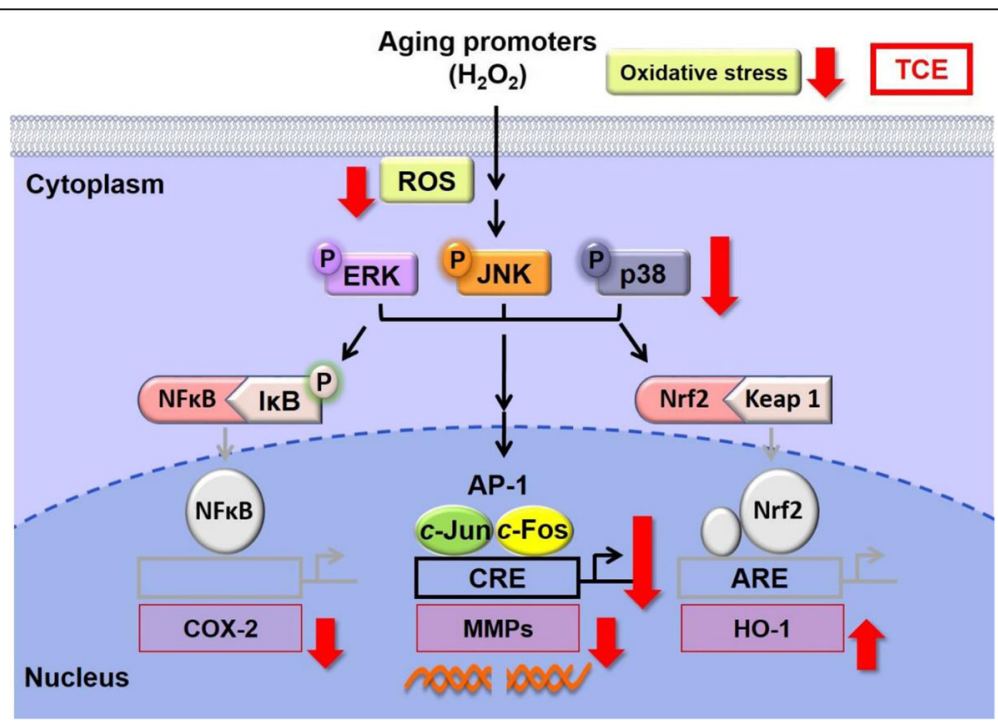

Fig. 4 Scheme for TCE inhibition of oxidative stress-induced skin damage. ( $\uparrow$ : upregulation; $\downarrow$ inhibition) 
example, Nrf2 has been reported to protect skin cells from UV- and pollutant-induced oxidative damage and cellular dysfunction [31]. On exposure to oxidative stress, Nrf2 is translocated to the cell nucleus and binds to antioxidant elements, activating phase II detoxification enzymes such as HO-1 and glutathione [32]. In the present study, $\mathrm{H}_{2} \mathrm{O}_{2}$ was found to reduce $\mathrm{HO}-1$ expression; however, TCE treatment increased HO-1 expression, alleviating $\mathrm{H}_{2} \mathrm{O}_{2}$-induced oxidative stress in the skin cells. In other words, TCE may repair or protect skin from the damage caused by superoxide peroxide and hydroxyl radicals.

Exposure of the skin to UV induces ROS generation and regulates the expression of genes and proteins, resulting in photodamage and photocarcinogenesis [7]. In addition, $\mathrm{H}_{2} \mathrm{O}_{2}$ has been reported to cause skin aging by inducing oxidative stress and MMP expression [33], while UVB-induced ROS generation triggers ERK, JNK, and p38 phosphorylation, AP-1 activation, and MMP expression, leading to collagen degradation [7]. In addition, $\mathrm{H}_{2} \mathrm{O}_{2}$ disrupts transforming growth factor beta transduction and subsequently inhibits collagen biosynthesis, inducing skin aging [8]. In the present study, $\mathrm{H}_{2} \mathrm{O}_{2}$ was determined to upregulate the phosphorylation of MAPKs, c-Jun, c-Fos, and MMP-1, -3 , and -9 proteins, whereas TCE inhibited these effects. This finding suggests that TCE activity is dependent on this signaling transduction. MMPs mediate degradation of ECM and play an important role in tissue homeostasis and remodeling including angiogenesis and tissue repair. Over suppression of MMPs may cause abnormal accumulation of ECM.

The results are consistent with those of our previous study, in which the T. catappa water extract protected skin from photodamage by inhibiting the MAPK/AP-1/MMP pathway [22]. UVB rays inhibited collagen synthesis and induced collagen degradation, whereas $T$. catappa water extract elevated the collagen content in Hs68 [22]. Similarly, in the present study, $\mathrm{H}_{2} \mathrm{O}_{2}$ was found to increase the collagen content in Hs68, whereas TCE reversed the effect. One previous study showed that $\mathrm{H}_{2} \mathrm{O}_{2}$ also reduces mRNA expression of type I collagen (COL1A1) in fibroblasts [34], although these results are inconsistent with those reported elsewhere. For example, researchers demonstrated that $\mathrm{H}_{2} \mathrm{O}_{2}$ induces oxidative stress damage to cells and the body, which can trigger the repair process of the skin, thereby increasing the collagen content. However, excessive collagen synthesis may cause collagen fibrosis and scleroderma [35]. Overall, our results here indicate that TCE can regulate the collagen content within a normal range.

\section{Conclusion}

The present study indicated that TCE with high polyphenic and flavonoid content exhibits potent free radical scavenging and antioxidant activity. Specifically, we determined that TCE protects against $\mathrm{H}_{2} \mathrm{O}_{2}$-induced skin damage by inhibiting the protein expression of MMP, AP-1, MAPKs, and COX-2 (Fig. 4). The antioxidant and antiaging activities of TCE make it suitable for application in skin care products.

\section{Additional file}

Additional file 1: S1. The active components in Terminalia catappa $\mathrm{L}$. methanolic extract (TCE). (DOCX $134 \mathrm{~kb})$

\section{Abbreviations}

AP-1: Activate protein-1; BHA: Beta hydroxyl acid; COX: Cyclooxygenase; DCFDA: 2',7'-dichlorofluorescin diacetate; DMEM: Dulbecco's Modified Eagle's Medium; ECM: Extracellular matrix; EDTA: Ethylenediaminetetraacetic acid; ELISA: Enzyme-linked immunosorbent assay; ERK: Extracellular signalregulated kinase; FBS: Fetal bovine serum; GAE: Gallic acid equivalent; $\mathrm{H}_{2} \mathrm{O}_{2}$ : Hydrogen peroxide; HO-1: Hemeoxygenase-1; JNK: C-Jun N-terminal kinase; MAPK: Mitogen-activated protein kinase; MMP: Matrix

metalloproteinase; MTT: 3-(4,5-dimethylthiazol-2-yl)-2,5-diphenyltetrazolium bromide; Nrf2: Nuclear factor E2-related factor 2; PBS: Phosphate buffered saline; QE: Quercetin equivalent; ROS: Reactive oxygen species;

TCE: Terminalia catappa L. methanolic extract; UV: Ultraviolet

\section{Acknowledgments}

Experiments and data analysis were partly performed at the Medical Research Core Facilities Center, Office of Research \& Development, at China Medical University, Taichung, Taiwan, R.O.C. Authors would like to express our very great appreciation to Ms. Jia-Ling Lyu, Ms. Yi-Jung Liu and Mr. Jyun-Shing Wu for their support in data analysis.

\section{Funding}

This study was sponsored by China Medical University (CMU103-ASIA-11; CMU105-ASIA-08), Taichung and the Ministry of Science and Technology (MOST 104-2320-B-039-006), Taipei, Taiwan.

\section{Availability of data and materials}

The datasets used and/or analysed during the current study are available from the corresponding author on reasonable request.

\section{Authors' contributions}

YHH performed the cell culture and experiments and analyzed the data; PYW, KCW, CYL and HMC conceived the study and participated in its design and coordination; and PYW, KCW, CYL, and HMC wrote and revised the paper. All authors read and approved the final manuscript.

Ethics approval and consent to participate Not applicable.

\section{Consent for publication}

Not applicable.

Competing interests

The authors declare that they have no competing interests.

\section{Publisher's Note}

Springer Nature remains neutral with regard to jurisdictional claims in published maps and institutional affiliations.

\section{Author details}

'Department of Cosmeceutics, China Medical University, 91 Hsueh-Shih Road, Taichung 40402, Taiwan. ${ }^{2}$ Department of Dermatology, China Medical University Hospital, Taichung 40402, Taiwan. ${ }^{3}$ School of Medicine, China Medical University, 91 Hsueh-Shih Road, Taichung 40402, Taiwan.

${ }^{4}$ Department of Biotechnology, Asia University, 500 Liufeng Road, Wufeng District, Taichung City 41354, Taiwan. 
Received: 27 April 2018 Accepted: 20 August 2018

Published online: 01 October 2018

\section{References}

1. Chen L, Hu JY, Wang SQ. The role of antioxidants in photoprotection: a critical review. J Am Acad Dermatol. 2012;67(5):1013-24.

2. Gilca GE, Stefanescu G, Badulescu O, Tanase DM, Bararu I, Ciocoiu M. Diabetic cardiomyopathy: current approach and potential diagnostic and therapeutic targets. J Diabetes Res. 2017;2017:1310265.

3. Ak T, Gulcin I. Antioxidant and radical scavenging properties of curcumin. Chem Biol Interact. 2008;174(1):27-37.

4. Lee $\mathrm{DH}$, Oh JH, Chung JH. Glycosaminoglycan and proteoglycan in skin aging. J Dermatol Sci. 2016;83(3):174-81.

5. Uitto J. The role of elastin and collagen in cutaneous aging: intrinsic aging versus photoexposure. J Drugs Dermatol. 2008;7(2 Suppl):s12-6.

6. Fisher GJ, Shao Y, He T, Qin Z, Perry D, Voorhees JJ, Quan T. Reduction of fibroblast size/mechanical force down-regulates TGF-beta type II receptor: implications for human skin aging. Aging Cell. 2016;15(1):67-76.

7. Kammeyer A, Luiten RM. Oxidation events and skin aging. Ageing Res Rev. 2015;21:16-29.

8. Bosch R, Philips N, Suarez-Perez JA, Juarranz A, Devmurari A, ChalensoukKhaosaat J, Gonzalez S. Mechanisms of photoaging and cutaneous photocarcinogenesis, and photoprotective strategies with phytochemicals. Antioxidants. 2015:4(2):248-68.

9. Fisher GJ, Wang ZQ, Datta SC, Varani J, Kang S, Voorhees J. Pathophysiology of premature skin aging induced by ultraviolet light. N Engl J Med. 1997;337(20):1419-28.

10. Kuo YH, Chen CW, Chu Y, Lin P, Chiang HM. In vitro and in vivo studies on protective action of $n$-phenethyl caffeamide against photodamage of skin. PLoS One. 2015;10(9):e0136777.

11. Kuo YH, Lin TY, You YJ, Wen KC, Sung PJ, Chiang HM. Antiinflammatory and antiphotodamaging effects of ergostatrien-3beta-ol, isolated from antrodia camphorata, on hairless mouse skin. Molecules. 2016;21(9). https://doi.org/ 10.3390/molecules21091213.

12. Bae JS, Han M, Shin HS, Kim MK, Shin CY, Lee DH, Chung JH. Perilla frutescens leaves extract ameliorates ultraviolet radiation-induced extracellular matrix damage in human dermal fibroblasts and hairless mice skin. J Ethnopharmacol. 2017:195:334-42

13. Kanlayavattanakul M, Lourith $\mathrm{N}$. An update on cutaneous aging treatment using herbs. J Cosmet Laser Ther. 2015;17(6):343-52.

14. Chen PS, Li JH, Liu TY, Lin TC. Folk medicine Terminalia catappa and its major tannin component, punicalagin, are effective against bleomycin-induced genotoxicity in Chinese hamster ovary cells. Cancer Lett. 2000;152(2):115-22.

15. Kinoshita S, Inoue Y, Nakama S, Ichiba T, Aniya Y. Antioxidant and hepatoprotective actions of medicinal herb, Terminalia catappa L. from Okinawa Island and its tannin corilagin. Phytomedicine. 2007;14(11):755-62.

16. Abiodun $\mathrm{OO}$, Rodriguez-Nogales A, Algieri F, Gomez-Caravaca AM, SeguraCarretero A, Utrilla MP, Rodriguez-Cabezas ME, Galvez J. Antiinflammatory and immunomodulatory activity of an ethanolic extract from the stem bark of Terminalia catappa L. (Combretaceae): in vitro and in vivo evidences. J Ethnopharmacol. 2016;192:309-19.

17. Anuracpreeda P, Chankaew K, Puttarak P, Koedrith P, Chawengkirttikul R, Panyarachun B, Ngamniyom A, Chanchai S, Sobhon P. The anthelmintic effects of the ethanol extract of Terminalia catappa $L$. leaves against the ruminant gut parasite, Fischoederius cobboldi. Parasitology. 2016;143(4):421-33.

18. Dikshit M, Samudrasok RK. Nutritional evaluation of outer fleshy coat of Terminalia catappa fruit in two varieties. Int J Food Sci Nutr. 2011;62(1):47-51.

19. Chandrasekhar Y, Ramya EM, Navya K, Phani Kumar G, Anilakumar KR. Antidepressant like effects of hydrolysable tannins of Terminalia catappa leaf extract via modulation of hippocampal plasticity and regulation of monoamine neurotransmitters subjected to chronic mild stress (CMS). Biomed Pharmacother. 2017:86:414-25.

20. Tercas AG, Monteiro AS, Moffa EB, Dos Santos JRA, de Sousa EM, Pinto ARB, Costa P, Borges ACR, Torres LMB, Barros Filho AKD, Fernandes ES, Monteiro CA. Phytochemical characterization of Terminalia catappa Linn. Extracts and their antifungal activities against Candida spp. Front Microbiol. 2017;8:595.

21. Khan AA, Kumar V, Singh BK, Singh R. Evaluation of wound healing property of Terminalia catappa on excision wound models in wistar rats. Drug Res. 2014;64(5):225-8.
22. Wen KC, Shih IC, Hu JC, Liao ST, Su TW, Chiang HM. Inhibitory effects of Terminalia catappa on uvb-induced photodamage in fibroblast cell line. Evid Based Complement Alternat Med. 2011;2011:904532.

23. Chiang HM, Chiu HH, Liao ST, Chen YT, Chang HC, Wen KC. Isoflavonoid-rich Flemingia macrophylla extract attenuates UVB-induced skin damage by scavenging reactive oxygen species and inhibiting MAP kinase and MMP expression. Evid Based Complement Alternat Med. 2013;2013:12.

24. Moein MR, Moein S, Ahmadizadeh S. Radical scavenging and reducing power of Salvia mirzayanii subfractions. Molecules. 2008;3(11):2804-13.

25. Esmaeili MA, Sonboli A. Antioxidant, free radical scavenging activities of Salvia brachyantha and its protective effect against oxidative cardiac cell injury. Food Chem Toxicol. 2010;48(3):846-53.

26. Ruch RJ, Cheng SJ, Klaunig JE. Prevention of cytotoxicity and inhibition of intercellular communication by antioxidant catechins isolated from Chinese green tea. Carcinogenesis. 1989;10(6):1003-8.

27. Wen KC, Chiu HH, Fan PC, Chen CW, Wu SM, Chang JH, Chiang HM. Antioxidant activity of Ixora parviflora in a cell/cell-free system and in UV-exposed human fibroblasts. Molecules. 2011;16(7):5735-52.

28. Wu PY, Huang CC, Chu Y, Huang YH, Lin P, Liu YH, Wen KC, Lin CY, Hsu MC, Chiang HM. Alleviation of ultraviolet B-induced photodamage by Coffea arabica extract in human skin fibroblasts and hairless mouse skin. Int J Mol Sci. 2017;18(4). https://doi.org/10.3390/ijms18040782.

29. Nichols JA, Katiyar SK. Skin photoprotection by natural polyphenols: antiinflammatory, antioxidant and DNA repair mechanisms. Arch Dermatol Res. 2010;302(2):71-83

30. Serteser A, Kargioglu M, Gok V, Bagci Y, Ozcan MM, Arslan D. Determination of antioxidant effects of some plant species wild growing in Turkey. Int J Food Sci Nutr. 2008;59(7-8):643-51.

31. Chaiprasongsuk A, Lohakul J, Soontrapa K, Sampattavanich S, Akarasereenont $P$, Panich U. Activation of Nrf2 reduces UVA-mediated MMP-1 upregulation via MAPK/AP-1 signaling cascades: the photoprotective effects of sulforaphane and hispidulin. J Pharmacol Exp Ther. 2017;360(3):388-98.

32. Kim YG, Sumiyoshi M, Sakanaka M, Kimura Y. Effects of ginseng saponins isolated from red ginseng on ultraviolet B-induced skin aging in hairless mice. Eur J Pharmacol. 2009;602(1):148-56.

33. Park MJ, Bae YS. Fermented Acanthopanax koreanum root extract reduces UVB- and $\mathrm{H}_{2} \mathrm{O}_{2}$-induced senescence in human skin fibroblast cells. J Microbiol Biotechnol. 2016;26(7):1224-33.

34. Park G, Jang DS. Oh MS. Juglans mandshurica leaf extract protects skin fibroblasts from damage by regulating the oxidative defense system. Biochem Biophys Res Commun. 2012;421(2):343-8.

35. McGaha TL, Phelps RG, Spiera H, Bona C. Halofuginone, an inhibitor of typeI collagen synthesis and skin sclerosis, blocks transforming-growth-factorbeta-mediated Smad3 activation in fibroblasts. J Investig Dermatol. 2002; 118(3):461-70
Ready to submit your research? Choose BMC and benefit from:

- fast, convenient online submission

- thorough peer review by experienced researchers in your field

- rapid publication on acceptance

- support for research data, including large and complex data types

- gold Open Access which fosters wider collaboration and increased citations

- maximum visibility for your research: over $100 \mathrm{M}$ website views per year

At $\mathrm{BMC}$, research is always in progress.

Learn more biomedcentral.com/submissions 